\title{
Does remuneration affect the discipline and the selection of politicians? Evidence from pay harmonization in the European Parliament
}

\author{
Thomas Braendle
}

Received: 16 June 2013/ Accepted: 15 May 2014/Published online: 22 June 2014

(C) Springer Science+Business Media New York 2014

\begin{abstract}
We study the harmonization of the base pay for the Members of the European Parliament (MEPs). Prior to this reform, implemented in 2009, base pay was aligned with that of national parliamentarians, causing large differences in pay between the MEPs representing 27 member states. Based on detailed information on individual MEPs between 2004 and 2011, we find that the reform, which introduced an exceptional base pay increase of $200 \%$ per national delegation on average, has a positive incentive effect on in-office effort proxied by the number of speeches, written declarations and reports drafted. However, more generous remuneration is associated with higher rates of absenteeism. With respect to political selection, we find that higher pay also raises reelection rates. The composition of the pool of MEPs in terms of (ex-ante) quality approximated by formal education, previous political experience in elected office and occupational background is, however, unaffected. If we restrict our attention to newly elected MEPs, a salary increase is related to fewer MEPs with previous political experience at the highest national level.
\end{abstract}

Keywords Political selection - Remuneration of politicians $\cdot$ Electoral system $\cdot$ European Parliament

JEL Classification $\quad$ D72 $\cdot$ D73

\section{Introduction}

There are two complementary perspectives on the role of institutions in political economy. On the one hand, traditional theory considers the role of institutions in disciplining political agents. This disciplining function is crucial to reducing the politician's incentives to shirk and to limiting the scope for rent-seeking, e.g., by means of regulation or direct income

T. Braendle $(\bowtie)$

Federal Department of Finance (FFA), University of Basel, Faculty of Business and Economics,

Bundesgasse 3, 3003 Berne, Switzerland

e-mail: thomas.braendle@efv.admin.ch 
transfers. ${ }^{1}$ On the other hand, current theory looks at how institutions impact the selection of politicians. This selection function is relevant because the electoral control of politicians and the credibility of policy commitments are limited, and thus the identity of politicians matters for political outcomes. ${ }^{2}$

In this paper, we want to bridge the theoretical gap. We focus on the remuneration of politicians as an important institutional determinant of the disciplining and selection effects. We exploit the exceptional European Parliament (EP) pay reform and investigate whether higher pay increases in-office effort and leads to a selection of better qualified politicians.

This paper pursues three main goals. First, using the exogenous variation in changes in pay across the national delegations from all 27 member countries, we study the impact of money on discipline. In particular, we analyze a broad set of measures ranging from absenteeism to engagement in legislative activities. Second, regarding the relationship between pay and selection, we study three important dimensions of the quality of politicians in detail, i.e., formal education, previous political experience in elected office and occupational background. Third, while there is a growing literature on the composition of the pool of politicians in (sub-)national assemblies in terms of quality, political economists and political scientists alike have paid relatively little attention to the supranational level. $\mathrm{We}$, therefore, thoroughly document who is elected to the EP. ${ }^{3}$

Harmonizing the base pay of Members of the European Parliament (MEPs) supplies an exceptional empirical opportunity for studying, on the one hand, the relationship between pay and discipline in politics, and, on the other hand, between pay and selection into politics. Until 2009, MEPs were paid out of national budgets and received the same base pay as their colleagues in national parliaments. For example, at the beginning of the 6th legislative period (LP6), i.e., the pre-harmonization period (2004-2009), an MEP from Hungary received an annual base salary of 10,080 euros, whereas an MEP from Italy was paid 144,084 euros. In 2005, the EP and the European Council enacted a new statute standardizing MEP salaries, to enter into force as of the beginning of the 7th legislative period (LP7) in July 2009. According to this reform, all MEPs would receive an identical base pay (91,983 euros in 2009). Since 2009 MEP salaries have been paid out of the EU budget and set at $38.5 \%$ of the pay of a judge of the European Court of Justice. All other items within the MEP's compensation package continue, as before 2009, to be financed out of the EU budget and are unaffected by the reform.

The question of how to measure a politician's discipline and quality are both subjects of on-going research (see Padovano 2013 for a discussion). With regard to discipline, we look at four different in-office indicators that serve as measures of effort, all being individually attributable. First, we analyze absenteeism as a proxy for shirking, as politicians may prefer

\footnotetext{
${ }^{1}$ For standard models of rent-seeking, see Tullock (1967), Buchanan et al. (1980), and Stigler (1971) for regulation. See Congleton et al. (2008) for an overview of research on rent-seeking. For a review of political shirking, see Bender and Lott (1996).

2 For a review of general ideas on the importance of selection in politics, see Fearon (1999), Brennan and Hamlin (2000), Besley (2005) and Mansbridge (2009). Recent research presents evidence showing that the identity of politicians matters for political outcomes, e.g., Chattopadhyay and Duflo (2004) and Jones and Olken (2005). An early contribution on the importance of politicians' occupational backgrounds is presented by Couch et al. (1992).

3 Survey-based exceptions in political science are Scarrow (1997), Norris and Franklin (1997), and Hobolt and Hoyland (2011). Meserve et al. (2012) explore determinants of the party list positioning of candidates in the 2009 European election for 12 countries.
} 
either leisure or to invest their time in earning outside income. ${ }^{4}$ Second, we more specifically investigate legislative activity, i.e., by studying parliamentarians' efforts as reflected in the number of plenary speeches, written declarations and reports drafted. Delivering speeches is an inherent part of a politician's (representational) duties and signals effort. Written declarations are a means by which politicians can draw the attention of parliament to matters of concern. Drafting reports is the most important instrument influencing legislation, as reports passed by majority vote are incorporated into EU legislation. With respect to (ex-ante) quality, we build upon and extend previous literature and concentrate on the dimensions of formal education, previous political experience in elected office and occupational background. Formal education is a proxy for ability in the private sector and is arguably positively related to ability in the political sector. We study two dimensions of formal education, i.e., the level of education and the field of study. Previous political experience at different levels of government (local, regional or national) is taken as an indicator of the role of elections as quality filters (see Cooter 2002). We assume that election to a position at higher levels of government reveals greater political quality (or at least more relevant political experience). In addition, we look at previous occupations and focus on two groups: MEPs with previous occupations in an area close to or actually in the political sector and those who have worked in highly skilled occupations (for instance, university professors, senior public officials and those practicing liberal professions, such as lawyers and architects). The first group contributes knowledge and a sound understanding of the political process, while the second group's competence has been displayed outside the realm of politics.

Based on our new dataset on the MEPs between 2004 and 2011, we exploit the enormous variation in the change of pay and use a fixed effects model controlling for timeinvariant and country-invariant unobserved heterogeneity. For the reform, which was not accompanied by any other institutional change, we find a positive incentive effect on inoffice legislative effort proxied by the number of speeches, written declarations and reports drafted. For example, a $10 \%$ increase in base pay is related to a $1.48 \%$ increase in the number of written declarations, on average. However, at the same time, higher remuneration is associated with more absenteeism. These results hold if we analyze sample restrictions according to national differences in electoral rules. With respect to selection, we find that more pay increases reelection rates. Doubling the base pay increases the probability of reelection by 17.7 percentage points. The composition of the pool of MEPs in terms of formal education, previous political experience and occupational background is, however, unaffected by the pay reform. If we restrict our attention to newly elected MEPs, we find that higher pay is related to fewer MEPs with previous political experience at the highest national level. Further, differentiating between the fields of study rather than between the levels of education indicates that more generous pay increases the fraction of MEPs with a law degree.

Overall, our results support the traditional view that the institutions that determine remuneration in politics have a bearing on the discipline of political agents. Little support is found for the (short-run) importance of more generous pay in systematically improving political selection. This finding, however, seems to be driven partly by electoral forces that benefit the incumbents and result in lower turnover. Moreover, one must take into account the European proportional electoral rule (which is fixed during our observation period) and

\footnotetext{
4 The absence rate as a proxy for shirking is used by Lott (1987) for the United States, Gagliarducci et al. (2010) for Italy and Besley and Larcinese (2011) for the United Kingdom.
} 
the correspondingly important role of national parties in nominating candidates and allocating them to either the (sub)national level or the European level.

Closest to our study is parallel work by Fisman et al. (2013) and Mocan and Altindag (2013), who also take advantage of this unique 'natural experiment'. Mocan and Altindag (2013) focus on the relationship between incentives and absenteeism and find a positive relationship. Work by Fisman et al. (2013) studies discipline and selection and thus overlaps with our own independent contribution. While they focus more on the analysis of effort and shirking, we concentrate on selection. In particular, based on a detailed dataset regarding individual MEP characteristics, we provide a differentiated analysis of the composition and selection effects of the reform on three ex-ante quality dimensions rather than on one, and present new results. In contrast to Fisman et al. (2013), we do not find that increases in pay reduce the quality of MEPs in terms of their formal education. Moreover, with regard to formal education, we look at whether the selection of politicians has changed in terms of their fields of study. We find similar results for incumbency. While Fisman et al. (2013) observe no systematic relationship between pay and in-office effort, we find that higher pay is related to more engagement in legislative activities, and, simultaneously, to more absenteeism. We provide a supplementary analysis of sample restrictions according to differences in electoral rules. ${ }^{5}$

Section 2 briefly discusses previous research. The institutional background is dealt with in Sect. 3. Section 4 presents the data and Sect. 5 the empirical analysis. Section 6 concludes.

\section{Previous literature}

Political agency models have analyzed the effect of salaries on the effort and shirking of politicians. For instance, in a model by Besley (2004) with the possibility of reelection, politicians are more likely to abstain from rent-seeking activities and behave more in line with citizens' preferences as the value of office holding increases. ${ }^{6}$ Political economists have more recently investigated how salaries influence the incentive to run for political office. Contributions to the research on politicians' pay and candidate selection have been made by Besley (2004), Caselli and Morelli (2004), Messner and Polborn (2004), Poutvaara and Takalo (2007) and Mattozzi and Merlo (2008) and provide mixed predictions. For instance, Caselli and Morelli (2004) present a citizen-candidate model. One central result is that higher relative pay in politics increases the average quality of politicians, as candidates with higher opportunity costs select into politics. In contrast, Poutvaara and Takalo (2007) introduce a two-party system and costly campaigning that generates informative but noisy signals about the quality of candidates. They show that the positive relationship between pay and the average quality of politicians need not hold and depends on the level of campaigning costs. ${ }^{7}$

\footnotetext{
${ }^{5}$ Early work on the selection of national senior bureaucrats and national politicians into the EC Commission, based on reputational or budgetary considerations, is carried out by Vaubel (1994). A public choice approach to the study of international organizations, in particular the EU, highlighting the severe principalagent problems is presented by Vaubel (2013).

${ }^{6}$ An early contribution which discusses salary as a disciplining device in politics is Barro (1973).

${ }^{7}$ Further institutions that have been addressed recently include the regime type (Besley and Reynal-Querol 2011), electoral rules and parties (Galasso and Nannicini 2011; Mattozzi and Merlo 2011), institutions enhancing transparency (Gehlbach et al. 2010; Rosenson 2006), and institutions which govern dual officeholding in different branches of government (Braendle and Stutzer 2010, 2011). For a first review, see Braendle (2013).
} 
Few contributions have addressed these questions empirically at the micro level. Ferraz and Finan (2009) and Gagliarducci and Nannicini (2013) analyze exogenous variation in the pay of local politicians and implement a (fuzzy) regression discontinuity design. Ferraz and Finan (2009) find that higher pay improves the performance of Brazilian local politicians (proxied by bill sponsorship and the provision of local public infrastructure) and attracts better qualified politicians (proxied by education and previous profession). Gagliarducci and Nannicini (2013) find that paying Italian mayors more reduces the size of municipal government and increases local bureaucratic efficiency. Regarding selection, they show that higher pay attracts candidates and elected mayors with higher opportunity costs as approximated by years of schooling and a white collar profession. Kotakorpi and Poutvaara (2011) apply a differences-in-differences approach to an increase of $35 \%$ in Finnish parliamentary pay at the national level. Using candidates in local elections as a control group, they find a five percentage point higher share of female candidates with university education. No effect is found for male candidates. Kotakorpi and Poutvaara (2011) argue that the gender gap that exists in outside wages and the fact that many highly educated women work in the public sector where the income distribution is narrower than in the private sector are plausible explanations. ${ }^{8}$

\section{European Parliament}

Electoral system: Since the EP was founded in 1979, direct elections have taken place every 5 years. Up to the elections in 1999, the EP was composed of 15 national delegations. In 2004, ten new member states from Eastern Europe joined and in 2007, Bulgaria and Romania also became EU member states. At the end of the 6th legislative period (in 2009), the EP consisted of 785 seats. As the EP has a proportional representation system, the delegation from Malta acquires the smallest number of seats (five seats in LP7) and Germany acquires the largest number (99 seats in LP7). All member states have proportional representation systems which differ in their specificities as to closed versus open lists, rules on incompatibility between the European and the national political arena, and minimum vote requirements. ${ }^{9}$ To the best of our knowledge, all of these specific institutions remained fixed within our observation period. By and large, election to the EP is based on the national party systems and, in combination with the proportional representation system, accords parties an important role in nominating candidates.

\subsection{Legislative competencies}

Most EU law and regulatory issues are decided by the co-decision procedure. This implies that the EP along with the European Council has the power to pass the budget and to adopt

\footnotetext{
${ }^{8}$ Whether higher pay impacts the incentive to rerun for political office is addressed by Groseclose and Krehbiel (1994) and Keane and Merlo (2010). Post-office earning possibilities are addressed by Eggers and Hainmueller (2009) and Parker and Parker (2009).

9 Estonia, France, Germany, Greece, Hungary, Spain, Portugal, Romania and the United Kingdom have a closed-list proportional representation system. The other member states have an open-list system. Ireland and Malta have a STV system in place (see Hix 2004). Rules of incompatibility which prohibit simultaneous dual office holding in the EP and the (sub-)national political assemblies apply in 22 member states (Lehmann 2009). Austria, Czech Republic, France, Germany, Greece, Hungary, Italy, Latvia, Lithuania, Poland, Romania, Slovakia and Sweden have minimum vote requirements for parties (Nohlen 2004).
} 
and amend legislation in many policy areas, such as immigration, energy, transportation, environmental and consumer protection. Apart from voting, MEPs have several instruments that they can use to influence the legislative decision-making process. The most common one is drafting legislative reports, where MEPs, called the rapporteurs, are entrusted by the responsible committee with amending proposals brought in by the European Commission. ${ }^{10}$ In addition to submitting reports, MEPs can influence the legislative process by, e.g., writing declarations in order to draw the attention of parliament to matters of concern.

Harmonization of base pay: The compensation package consists of a basic monthly salary and allowances. Allowances include a per-diem compensation for each plenary sitting day that is attended (304 euros in 2011). ${ }^{11}$ In addition, there are reimbursements for expenses associated with the MEP's costs of running a local office (4,299 euros), travelling (the effective travelling costs are reimbursed but not more than 0.5 euros per kilometer distance) and staff (up to 19,700 euros monthly for employed assistants). These allowances have always been paid by the EU and are not affected by the base pay harmonization. Prior to the 7th legislative period, the monthly basic salary was fixed and financed by the MEP's home country and equal to that of national parliamentarians. At the beginning of the 7th legislative period, the new statute for MEPs, enacted by the European Council and the EP in summer 2005, was adopted and requires the harmonization of pay. Since July 2009, all MEPs have received a base pay equal to $38.5 \%$ of the pay of a judge of the European Court of Justice, which is now disbursed from the EU budget. This was equivalent to 91,983 euros in July 2009. ${ }^{12}$ Table 1 displays the respective changes in base pay for all member states. The Eastern European delegations, the Spanish, the Portuguese, the Finnish and the Swedish delegations benefited most from the pay reform, while Italy and Austria had to accept reductions in base pay. The harmonization led to a base pay increase of $211 \%$ on average, and of $186 \%$ if corrected for changes in GDP. ${ }^{13}$

\footnotetext{
${ }^{10}$ See Mamadouh and Raunio (2003), Kaeding (2004) and Benedetto (2005) for the importance and the determinants of report allocation in the EP. Major determinants of rapporteurship allocation identified by the literature, such as country of origin, party affiliation and tenure are taken into account in our empirical analysis.

11 MEPs attending all plenary sitting days in 1 year earn approximately 18,000 euros in per-diem allowances.

12 The new statute allows incumbent MEPs to continue receiving the former, nationally based remuneration as long as they remain in parliament. However, we do not have information on those MEPs who opted to retain the old pay scheme. According to the parallel work by Fisman et al. (2013), only 33 MEPs opted for the old scheme. Fisman et al. (2013) identify only five out of these 33 members.

13 For the states that were EU members before the expansion in 2004, the harmonization implied a significantly larger increase than those that had taken place during the period prior to EU enlargement. Ideally, we would like to have information on salary development for earlier periods in order to better rule out a pre-treatment time trend in pay. However, such information is not available. The Netherlands and Ireland are the only member states that had experienced larger increases in the period before harmonization. In robustness checks, we controlled for the sensitivity of our results by excluding the Dutch and the Irish delegations, the delegations that entered later (Bulgaria and Romania), and the delegations that experienced reductions in pay (Austria and Italy). For all three exercises, we found similar results.
} 
Table 1 Annual base pay before and after the reform in 2009 in euro

\begin{tabular}{|c|c|c|c|c|c|}
\hline Country & $\begin{array}{l}\text { National } \\
\text { delegation } \\
\text { size }\end{array}$ & $\begin{array}{l}\text { Before reform } \\
\text { (in 2004) }\end{array}$ & $\begin{array}{l}\text { After reform } \\
\text { (in 2009) }\end{array}$ & $\begin{array}{l}\text { Change } \\
\text { in } \%\end{array}$ & $\begin{array}{l}\text { Change in } \\
\% \text { corrected } \\
\text { for GDP/capita }\end{array}$ \\
\hline Hungary & 22 & 10,080 & 91,983 & 813 & 798 \\
\hline Bulgaria & 17 & 10,226 & 91,983 & 800 & 675 \\
\hline Latvia & 8 & 12,518 & 91,983 & 635 & 567 \\
\hline Slovakia & 13 & 14,085 & 91,983 & 553 & 416 \\
\hline Lithuania & 12 & 14,197 & 91,983 & 548 & 467 \\
\hline Malta & 5 & 15,534 & 91,983 & 492 & 442 \\
\hline Czech Republic & 22 & 19,774 & 91,983 & 365 & 306 \\
\hline Romania & 33 & 21,746 & 91,983 & 323 & 294 \\
\hline Estonia & 6 & 21,864 & 91,983 & 321 & 295 \\
\hline Poland & 50 & 28,860 & 91,983 & 219 & 154 \\
\hline Spain & 50 & 38,396 & 91,983 & 140 & 137 \\
\hline Portugal & 22 & 48,286 & 91,983 & 90 & 89 \\
\hline Slovenia & 7 & 48,815 & 91,983 & 88 & 70 \\
\hline Cyprus & 6 & 52,041 & 91,983 & 77 & 65 \\
\hline Finland & 13 & 59,640 & 91,983 & 54 & 50 \\
\hline Sweden & 18 & 62,069 & 91,983 & 48 & 47 \\
\hline Luxembourg & 6 & 63,791 & 91,983 & 44 & 36 \\
\hline Denmark & 13 & 69,816 & 91,983 & 32 & 34 \\
\hline Belgium & 22 & 72,018 & 91,983 & 28 & 25 \\
\hline Greece & 22 & 73,850 & 91,983 & 25 & 15 \\
\hline France & 72 & 81,273 & 91,983 & 13 & 12 \\
\hline United Kingdom & 72 & 83,312 & 91,983 & 10 & 11 \\
\hline Ireland & 12 & 83,712 & 91,983 & 10 & 15 \\
\hline Germany & 99 & 84,108 & 91,983 & 9 & 6 \\
\hline Netherlands & 25 & 86,126 & 91,983 & 7 & 1 \\
\hline Austria & 17 & 106,583 & 91,983 & -14 & -18 \\
\hline Italy & 72 & 144,084 & 91,983 & -36 & -32 \\
\hline Average & 28.17 & 52,845 & 91,983 & 211 & 184 \\
\hline
\end{tabular}

The national delegation size is shown for the beginning of the 7 th legislative period. The values show the annual base pay at the beginning of the 6th and the 7 th legislative periods in euro. For Bulgaria and Romania, which became members of the European Parliament in 2007, the values report the basic salary paid before the reform as the average of the years 2007-2009

Sources See Table 2

\section{Data}

\subsection{Data sources}

The information on base pay is taken mainly from Corbett et al. (2005) and the European Parliament Information Bureau in Germany. With regard to information on the individual MEPs, the primary source is the official MEP register entry provided by the EP documentation service. For many MEPs, voluntarily submitted curricula vitae are available, 
which ideally contain information about formal education, previous political experience in elected office and occupational background. For MEPs who were elected for the 6th legislative period, though not reelected for the 7th legislative period, we had to refer to other sources, such as the 'watchdog' organizations: Votewatch, Powerbase or La Quadrature du Net. Moreover, we checked the personal homepages of MEPs and party homepages in order to supplement or validate incomplete information retrieved from the EP. ${ }^{14}$ The information on the in-office effort measures is taken from the EP and Votewatch.

\subsection{Background of politicians: classification and descriptive statistics}

We concentrate on three main ex-ante quality indicators: formal education, political experience and occupation prior to election to the EP. The classification of these quality dimensions and the corresponding summary statistics are described and shown in Table 2 (see below). ${ }^{15}$

Formal education: Formal education is a proxy for ability in the private sector and is arguably positively related to ability in the political sector. We identify the most advanced formal degree obtained. Out of all 1,319 MEPs in the 6th and 7th legislative period, $87 \%$ indicate that they have at least one degree from an institution of tertiary education (bachelor's, master's or doctoral degrees). The share of MEPs with a doctoral degree or superior qualifications is $26 \%$, which is a rather high percentage compared to national parliaments (see Merlo et al. 2010 for Italy and Schindler 1999 for Germany). When looking at the total of 54 delegations (27 member states multiplied by two legislative periods), interesting differences emerge. The national delegation with the largest share of MEPs with a doctoral degree is Latvia with $75 \%$ in the 7th legislative period (LP7), whereas several national delegations, such as Luxembourg, Ireland, Finland (LP7), Estonia (LP7) and Denmark (LP7) do not have any members with a doctoral degree. In all, 20 out of 54 delegations do not have any members lacking a tertiary education.

Previous political experience: Our focus is on whether the MEP was elected prior to becoming an MEP to either a local, a regional or a national executive office or legislative mandate. We assume that election to a position at higher levels of government reveals greater political quality. MEPs indicate that their previous highest position held was local (14\%), regional (12\%) and national (39\%). For $35 \%$ of the MEPs, no information is available. Most likely, this indicates that these MEPs possessed no prior political experience in elected office rather than that there is a gap in the information, as politicians tend to report each previous political position held. Regarding the composition of national delegations, again marked differences emerge. The highest share of MEPs with local political experience is found for the French delegation, i.e., $31 \%$. The highest share for the regional level is found in Italy $(27.4 \%)$ and in Latvia (100\%) for the national level.

Previous occupation: Based on the last occupational position held before first election to the EP, we are particularly interested in two categories. The first category consists of MEPs with a previous occupation in an area close to politics. This group contributes knowledge and a sound understanding of the political process. It includes professional

\footnotetext{
${ }^{14}$ We used these further sources when information was available in English, French, German, Italian, Polish and Spanish. In some cases, we referred to Wikipedia which provided further sources or information.

15 Table A.1 in the Online Appendix provides more detailed information on the classification and Table A.2 in the Online Appendix shows corresponding summary statistics at the delegation level. The Online Appendix is available at http://wwz.unibas.ch/personen/profil/person/bra/
} 
Table 2 Descriptive statistics

\begin{tabular}{|c|c|c|c|c|c|}
\hline & Obs. & Mean & SD & Min. & Max. \\
\hline \multicolumn{6}{|l|}{ MEP characteristics } \\
\hline Female & 1,319 & 0.31 & 0.46 & 0 & 1 \\
\hline Age & 1,319 & 49.45 & 10.61 & 21 & 90 \\
\hline Tenure & 1,319 & 1.46 & 0.91 & 1 & 6 \\
\hline \multicolumn{6}{|l|}{ Ideology } \\
\hline European People's Party (EPP) & 1,319 & 0.35 & 0.48 & 0 & 1 \\
\hline Progressive Alliance of Socialists and Democrats (S\&D) & 1,319 & 0.28 & 0.45 & 0 & 1 \\
\hline Alliance of Liberals and Democrats for Europe (ALDE) & 1,319 & 0.13 & 0.33 & 0 & 1 \\
\hline Green/European Free Alliance (EFA) & 1,319 & 0.06 & 0.24 & 0 & 1 \\
\hline European United Left-Nordic Green Left (GUE/NGL) & 1,319 & 0.05 & 0.22 & 0 & 1 \\
\hline Europe of Freedom and Democracy (EFD) & 1,319 & 0.02 & 0.13 & 0 & 1 \\
\hline European Conservatives and Reformist (ECR) & 1,319 & 0.02 & 0.13 & 0 & 1 \\
\hline Union for Europe of the Nations (UEN) & 1,319 & 0.03 & 0.18 & 0 & 1 \\
\hline Independence/Democracy Group (Ind/Dem) & 1,319 & 0.02 & 0.14 & 0 & 1 \\
\hline Non-affiliated members & 1,319 & 0.04 & 0.20 & 0 & 1 \\
\hline \multicolumn{6}{|l|}{ Education, political and occupational experience } \\
\hline No educational information & 1,319 & 0.04 & 0.19 & 0 & 1 \\
\hline Low to middle level of education & 1,319 & 0.10 & 0.29 & 0 & 1 \\
\hline University degree (without Ph.D./M.D.) & 1,319 & 0.61 & 0.49 & 0 & 1 \\
\hline Doctoral degree or more & 1,319 & 0.26 & 0.44 & 0 & 1 \\
\hline Degree in law & 1,319 & 0.20 & 0.40 & 0 & 1 \\
\hline Degree in economics or business administration & 1,319 & 0.13 & 0.33 & 0 & 1 \\
\hline Degree in other social sciences & 1,319 & 0.25 & 0.43 & 0 & 1 \\
\hline No political experience information & 1,319 & 0.35 & 0.48 & 0 & 1 \\
\hline Local political experience & 1,319 & 0.14 & 0.35 & 0 & 1 \\
\hline Regional political experience & 1,319 & 0.12 & 0.33 & 0 & 1 \\
\hline National political experience & 1,319 & 0.39 & 0.49 & 0 & 1 \\
\hline No occupational experience & 1,319 & 0.04 & 0.18 & 0 & 1 \\
\hline Occupations close to politics & 1,319 & 0.25 & 0.43 & 0 & 1 \\
\hline Highly skilled occupations & 1,319 & 0.37 & 0.48 & 0 & 1 \\
\hline Other occupations & 1,319 & 0.34 & 0.47 & 0 & 1 \\
\hline \multicolumn{6}{|l|}{ Position in parliament } \\
\hline Committee chair & 1,319 & 0.02 & 0.15 & 0 & 1 \\
\hline Delegation chair & 1,319 & 0.04 & 0.20 & 0 & 1 \\
\hline \multicolumn{6}{|l|}{ Measures of in-office effort } \\
\hline Absence rate & 606 & 10.71 & 8.66 & 0 & 47.41 \\
\hline Number of plenary speeches & 604 & 43.22 & 64.16 & 0 & 649 \\
\hline Number of written declarations & 606 & 0.70 & 1.28 & 0 & 11 \\
\hline Number of reports drafted & 606 & 1.20 & 2.44 & 0 & 28 \\
\hline \multicolumn{6}{|l|}{ Variables at delegation level } \\
\hline Share of women & 54 & 32.69 & 12.46 & 0 & 60 \\
\hline Share of incumbents & 30 & 46.21 & 15.12 & 12.90 & 77.11 \\
\hline Ln(remuneration) & 54 & 11.02 & 0.69 & 9.22 & 11.88 \\
\hline
\end{tabular}


Table 2 continued

\begin{tabular}{lccccc}
\hline & Obs. & Mean & SD & Min. & Max. \\
\hline Ln(GDP) & 54 & 9.53 & 0.83 & 7.70 & 10.96 \\
Corruption index & 54 & 6.36 & 1.91 & 2.9 & 9.7 \\
National delegation size & 54 & 28.17 & 25.52 & 5 & 99 \\
\hline
\end{tabular}

There are 1,319 MEPs who served between 2004 and 2011. Among these 1,319 MEPs, there are around 180 MEPs who retired early and a similar number of MEPs who replaced them. If the MEP is member of both legislative assemblies, the descriptive statistics are indicated for the first period. Tenure is indicated as the number of previous memberships in legislative periods. In the 7th legislative period, there were seven political groups. EFD and ECR are new political groups formed at the beginning of the 7th legislative period. ECR is a splinter party that broke away from EPP. It is composed of MEPs who were previously members of the EPP, UEN and Ind/Dem. UEN and Ind/Dem no longer had sufficient membership to form independent political groups. Therefore, MEPs from these parties formed EFD on 1 July 2009. 27 MEPs $(3.6 \%)$ are not affiliated with a party. University degree includes Bachelor's or Master's degree at universities or at colleges of education, technical colleges, higher schools of applied sciences as well as postgraduate studies. Doctoral degree or more includes Ph.D. or M.D. and superior qualifications such as university lecturer and assistant/full professor. Degree in other social sciences: Political science and international relations, sociology, psychology, history and journalism. Previous local political experience: Member of the local legislative assembly/local council and elected executive positions such as mayor. Previous regional political experience: Member of the regional parliament and executive positions such as president/head of government of the region or regional minister. Previous national political experience: Member of the national parliament or senate as well executive positions such as president, prime minister, chancellor, and national minister. Previous occupation close to politics includes professional/(full-time) politicians (head of government, minister or member of parliament or senate during the 10 years prior to election to the EP and no other simultaneous employment), full-time party officials or employees of a politician, and trade union/trade association officials. Highly skilled occupations: Assistant/full professors at an institution of tertiary education, senior public officials (leading position in various fields of public administration such as judge, ambassador or diplomat), senior employees in the private sector, liberal professions (lawyer and notary as well as pharmacist, physician, architect and accountant) and selfemployed and entrepreneurs. The values for the measures of in-office effort summarize the 6 th and the 7 th legislative periods for each MEP in the subsample of MEPs who were members in the two first years of each legislative period (without MEPs who retired early, replaced them or belonged to the national delegations from Bulgaria and Romania). Ln(remuneration) is defined as the logarithm of the base pay at the beginning of the 6th or 7th legislative period. The values have been taken from Corbett et al. (2005) and the European Parliament Information Bureau in Germany (www.europarl.de). For Bulgaria and Romania in the 6th legislative period, the values have been complemented with information from Mocan and Altindag (2013). The share of incumbents refers to the 15 member states before EU enlargement in 2004. Ln(GDP) in the year of election is taken from the World Development Indicators. The corruption index for the year of election has been taken from Transparency International. It is scaled from 0 to 10, where 10 indicates the lowest level of perceived corruption

politicians (i.e., full-time politicians), party officials or assistants to politicians and trade union or trade association officials. The second category aims at capturing politicians who had highly skilled and highly paid occupations outside politics. It includes white collar workers such as university professors, senior public officials, those practicing liberal professions (such as lawyers, architects, etc.), senior employees in the private sector, entrepreneurs and self-employed. On average, $25.4 \%$ of all MEPs indicate that they had a previous occupation that was closely associated with politics or that they were actually in politics. The respective figure for the category highly skilled occupation is $37.1 \%$. At the national delegation level, the share of MEPs with a prior occupation close to politics varies strongly. It is lowest for Lithuania in LP6 $(7.1 \%)$ and largest for Estonia in LP6 $(85.7 \%)$. 


\section{Empirical analysis}

We investigate three major issues. We start with an analysis of the relationship between the pay reform and four measures of in-office effort. Subsequently, we focus on the effect on political selection. Finally, we analyze the relationship between pay and incumbency.

\subsection{Pay harmonization and in-office effort}

We apply the following OLS model to our micro data:

$$
\begin{aligned}
& \text { Measure of effort } \mathrm{i}_{\mathrm{d}, \mathrm{t}}=\beta_{0}+\beta_{1} \ln \left(\text { remuneration }_{\mathrm{d}, \mathrm{t}}\right)+\beta_{2} \mathrm{LP} 7+\beta_{3} \mathrm{D}_{\mathrm{d}}+\beta_{4} \mathrm{X}_{\mathrm{d}, \mathrm{t}}+\beta_{5} \mathrm{Z}_{\mathrm{i}, \mathrm{d}, \mathrm{t}} \\
& +\epsilon_{\mathrm{i}, \mathrm{d}, \mathrm{t}} \text {, }
\end{aligned}
$$

where the dependent variable is the absence rate in percentage or the natural logarithm of the number of plenary speeches, written declarations or reports drafted of individual $i$ who belongs to national delegation $d$ in legislative period $t$ (LP6 or LP7). ${ }^{16}$ We include the base pay in natural logarithmic terms for national delegation $d$ at the beginning of legislative period $t . L P 7$ is an indicator variable of the post-harmonization legislative period. It is included to capture a common time trend, for instance when highly contested political issues lead to greater effort by politicians, in the absence of an institutional change. The national delegation fixed effects are denoted by $D_{d}$ and are included to account for unobserved country specific time-invariant factors impacting in-office effort. ${ }^{17,18}$ The vector $X_{d, t}$ includes characteristics common to the MEPs from a certain member state, i.e., $\ln (\mathrm{GDP})$, the Corruption Perceptions Index, the size of the political group as well as the size of the national delegation. The variables $\ln (\mathrm{GDP})$ and the Corruption Perceptions Index are introduced to approximate major socio-economic country characteristics. The size of the political group and the size of the national delegation are included to take the possibility of peer pressure into account. Peer pressure decreases with the size of the group and may thus increase the incentive to shirk. The vector $Z_{i, d, t}$ captures MEP characteristics such as gender, age, tenure, party affiliation, educational, political and occupational background and whether or not the MEP is chairing a committee or a delegation. These characteristics are potentially correlated with in-office effort. The error term is denoted by $\epsilon$. Our variable of interest varies across national delegations. Therefore, we calculate clustered standard errors at this level to take into account intra-delegation correlation and correlation of the national delegation over time. As we are interested in the incentive effect of the reform, we restrict our attention to the MEPs who experienced the exogenous change in pay, i.e., the MEPs elected for both legislative periods. We compare the effort during the first 2 years of each legislative period, i.e., 2004-2006 and 2009-2011.

\footnotetext{
${ }^{16}$ Given that the dependent variables, plenary speeches, written declarations and reports drafted are logarithmized, we estimate specifications of a semilogarithmic functional form. Accordingly, the coefficient for a continuous variable shows the percentage change in the untransformed dependent variable per one-unit change in the explanatory factor. However, this interpretation of the estimated coefficients does not hold for categorical variables. Therefore, we also report estimated mean coefficients (in square brackets) that are consistent, close to the unbiased results and follow the interpretation of coefficients for continuous variables (Kennedy 1981).

17 Examples of such factors might be time-invariant differences in national institutions or national delegation-specific political cultures that influence the engagement in legislative activities.

18 As we look at two periods, our fixed effects estimation approach in levels is analytically the same as looking at first differences.
} 
Table 3 The effects of remuneration on in-office effort

\begin{tabular}{|c|c|c|c|c|}
\hline Dependent variable & $\begin{array}{l}\mathrm{I} \\
\text { Absence } \\
\text { rate }\end{array}$ & $\begin{array}{l}\text { II } \\
\text { Plenary } \\
\text { speeches }\end{array}$ & $\begin{array}{l}\text { III } \\
\text { Written } \\
\text { declarations }\end{array}$ & $\begin{array}{l}\text { IV } \\
\text { Reports } \\
\text { drafted }\end{array}$ \\
\hline $\ln ($ remuneration $)$ & $\begin{array}{l}1.352 * \\
(0.77)\end{array}$ & $\begin{array}{l}0.168 * * \\
(0.07)\end{array}$ & $\begin{array}{l}0.148 * * * \\
(0.05)\end{array}$ & $\begin{array}{l}0.105 \\
(0.06)\end{array}$ \\
\hline LP7 & $\begin{array}{l}0.003 \\
(1.30)\end{array}$ & $\begin{array}{l}0.137 \\
(0.13) \\
{[.138]}\end{array}$ & $\begin{array}{l}0.247 * * * \\
(0.07) \\
{[0.278]}\end{array}$ & $\begin{array}{l}-0.119 * \\
(0.07) \\
{[-0.114]}\end{array}$ \\
\hline $\ln (\mathrm{GDP})$ & $\begin{array}{l}3.778 \\
(13.15)\end{array}$ & $\begin{array}{l}-0.130 \\
(1.48)\end{array}$ & $\begin{array}{l}-1.620 * * \\
(0.64)\end{array}$ & $\begin{array}{l}1.238 * \\
(0.66)\end{array}$ \\
\hline Corruption & $\begin{array}{l}-1.530 \\
(1.65)\end{array}$ & $\begin{array}{l}0.247 \\
(0.15)\end{array}$ & $\begin{array}{l}0.086 \\
(0.05)\end{array}$ & $\begin{array}{l}-0.043 \\
(0.06)\end{array}$ \\
\hline Political group size & $\begin{array}{l}0.009 \\
(0.10)\end{array}$ & $\begin{array}{l}-0.016^{* *} \\
(0.01)\end{array}$ & $\begin{array}{l}0.001 \\
(0.00)\end{array}$ & $\begin{array}{l}-0.002 \\
(0.00)\end{array}$ \\
\hline National delegation size & $\begin{array}{l}0.119 \\
(0.33)\end{array}$ & $\begin{array}{l}-0.046 \\
(0.03)\end{array}$ & $\begin{array}{l}0.039 * * * \\
(0.01)\end{array}$ & $\begin{array}{l}0.008 \\
(0.01)\end{array}$ \\
\hline Woman & $\begin{array}{l}0.002 \\
(0.82)\end{array}$ & $\begin{array}{l}0.113 \\
(0.09) \\
{[0.114]}\end{array}$ & $\begin{array}{l}-0.063 \\
(0.06) \\
{[-0.063]}\end{array}$ & $\begin{array}{l}0.068 \\
(0.05) \\
{[-0.069]}\end{array}$ \\
\hline Age & $\begin{array}{l}-0.084 \\
(0.06)\end{array}$ & $\begin{array}{l}-0.017 * * * \\
(0.01)\end{array}$ & $\begin{array}{l}-0.001 \\
(0.00)\end{array}$ & $\begin{array}{l}-0.002 \\
(0.00)\end{array}$ \\
\hline Tenure & $\begin{array}{l}-0.047 \\
(0.47)\end{array}$ & $\begin{array}{l}0.188 * * * \\
(0.03)\end{array}$ & $\begin{array}{l}-0.013 \\
(0.03)\end{array}$ & $\begin{array}{r}0.062 \\
* * * \\
(0.02)\end{array}$ \\
\hline EPP & $\begin{array}{l}-6.975 \\
(23.21)\end{array}$ & $\begin{array}{l}{[5.865]} \\
3.518 * \\
(1.78)\end{array}$ & $\begin{array}{l}{[-0.639]} \\
-0.697 \\
(0.80)\end{array}$ & $\begin{array}{l}{[0.490]} \\
1.039 \\
(1.13)\end{array}$ \\
\hline S\&D & $\begin{array}{l}-6.190 \\
(16.29)\end{array}$ & $\begin{array}{l}2.293 * \\
(1.30) \\
{[3.227]}\end{array}$ & $\begin{array}{l}-0.524 \\
(0.59) \\
{[-0.502]}\end{array}$ & $\begin{array}{l}0.781 \\
(0.77) \\
{[0.618]}\end{array}$ \\
\hline ALDE & $\begin{array}{l}-4.661 \\
(5.25)\end{array}$ & $\begin{array}{l}0.923 \\
(0.57) \\
{[1.114]}\end{array}$ & $\begin{array}{l}-0.323 \\
(0.30) \\
{[-0.308]}\end{array}$ & $\begin{array}{l}0.549 \\
(0.35) \\
{[0.629]}\end{array}$ \\
\hline EFA & $\begin{array}{l}-6.049 \\
(3.58)\end{array}$ & $\begin{array}{l}0.299 \\
(0.36) \\
{[0.263]}\end{array}$ & $\begin{array}{l}-0.134 \\
(0.24) \\
{[-0.151]}\end{array}$ & $\begin{array}{l}0.514 * * \\
(0.20) \\
{[0.639]}\end{array}$ \\
\hline GUE/NGL & $\begin{array}{l}-0.076 \\
(4.49)\end{array}$ & $\begin{array}{l}0.211 \\
(0.35) \\
{[0.161]}\end{array}$ & $\begin{array}{l}-0.382 * \\
(0.20) \\
{[-0.331]}\end{array}$ & $\begin{array}{l}0.372 * * \\
(0.17) \\
{[0.429]}\end{array}$ \\
\hline Other party & $\begin{array}{l}0.515 \\
(3.16)\end{array}$ & $\begin{array}{l}0.072 \\
(0.45) \\
{[-0.027]}\end{array}$ & $\begin{array}{l}-0.651 * * * \\
(0.20) \\
{[-0.488]}\end{array}$ & $\begin{array}{l}0.382 * \\
(0.22) \\
{[0.429]}\end{array}$ \\
\hline University degree & $\begin{array}{l}-0.436 \\
(1.27)\end{array}$ & $\begin{array}{l}-0.202 \\
(0.23) \\
{[-0.204]}\end{array}$ & $\begin{array}{l}0.053 \\
(0.05) \\
{[-0.054]}\end{array}$ & $\begin{array}{l}-0.003 \\
(0.07) \\
{[-0.006]}\end{array}$ \\
\hline At least local political experience & $\begin{array}{l}1.207 \\
(1.02)\end{array}$ & $\begin{array}{l}0.036 \\
(0.09) \\
{[0.033]}\end{array}$ & $\begin{array}{l}-0.014 \\
(0.05) \\
{[-0.016]}\end{array}$ & $\begin{array}{l}-0.041 \\
(0.06) \\
{[-0.042]}\end{array}$ \\
\hline Occupation close to politics & $\begin{array}{l}4.028 \\
(4.28)\end{array}$ & $\begin{array}{l}0.041 \\
(0.18) \\
{[0.026]}\end{array}$ & $\begin{array}{l}0.134 \\
(0.16) \\
{[0.128]}\end{array}$ & $\begin{array}{l}-0.015 \\
(0.13) \\
{[-0.024]}\end{array}$ \\
\hline
\end{tabular}


Table 3 continued

\begin{tabular}{|c|c|c|c|c|}
\hline Dependent variable & $\begin{array}{l}\text { I } \\
\text { Absence } \\
\text { rate }\end{array}$ & $\begin{array}{l}\text { II } \\
\text { Plenary } \\
\text { speeches }\end{array}$ & $\begin{array}{l}\text { III } \\
\text { Written } \\
\text { declarations }\end{array}$ & $\begin{array}{l}\text { IV } \\
\text { Reports } \\
\text { drafted }\end{array}$ \\
\hline Highly skilled occupation & $\begin{array}{l}2.739 \\
(4.67)\end{array}$ & $\begin{array}{l}0.225 \\
(0.16) \\
{[0.236]}\end{array}$ & $\begin{array}{l}0.200 \\
(0.18) \\
{[0.203]}\end{array}$ & $\begin{array}{l}0.037 \\
(0.15) \\
{[0.026]}\end{array}$ \\
\hline Other occupation & $\begin{array}{l}2.700 \\
(4.57)\end{array}$ & $\begin{array}{l}0.030 \\
(0.19) \\
{[0.012]}\end{array}$ & $\begin{array}{l}0.200 \\
(0.15) \\
{[0.206]}\end{array}$ & $\begin{array}{l}0.066 \\
(0.12) \\
{[0.060]}\end{array}$ \\
\hline Committee chair & $\begin{array}{l}-3.232 * * * \\
(1.00)\end{array}$ & $\begin{array}{l}0.327 * * \\
(0.13) \\
{[0.374]}\end{array}$ & $\begin{array}{l}0.288 * \\
(0.16) \\
{[0.316]}\end{array}$ & $\begin{array}{c}1.018 \\
* * * \\
(0.12) \\
{[1.748]}\end{array}$ \\
\hline Delegation chair & $\begin{array}{l}0.648 \\
(1.92)\end{array}$ & $\begin{array}{l}0.014 \\
(0.12) \\
{[0.007]}\end{array}$ & $\begin{array}{l}-0.055 \\
(0.09) \\
{[-0.057]}\end{array}$ & $\begin{array}{l}-0.002 \\
(0.15) \\
{[-0.014]}\end{array}$ \\
\hline Country fixed effects & yes & yes & yes & yes \\
\hline No. of observations & 606 & 604 & 606 & 606 \\
\hline No. of clusters & 25 & 25 & 25 & 25 \\
\hline $\mathrm{R}^{2}$ & .136 & .290 & .186 & .189 \\
\hline
\end{tabular}

Partial correlations from OLS regressions. Robust standard errors clustered at the country (national delegation) level in parentheses. Significance levels: $* .05<p<.1, * * .01<p<.05$, *** $p<.01$. Dependent variable in column I: absence rate in percentage, in column II: $\ln$ (number of speeches), in column III: $\ln$ (number of written declarations) and in column IV: $\ln$ (number of reports drafted). In columns II-IV, we apply a $\ln (n+1)$ transformation in order to make use of the MEPs who did not deliver speeches or did not submit written declarations or reports. LP7 stands for 7th legislative period. The sample includes all MEPs elected for the 6th and re-elected for the 7th legislative period who were MEPs for the whole two first years in both legislative periods $(\mathrm{N}=303)$. Excluded are MEPs who retired earlier or their successors, and the MEPs from Bulgaria and Romania who joined in 2007. Other party captures EFD, ECR, UEN or Ind/Dem. The reference category is non-affiliated members. The reference category for occupational background is no occupation indicated. For further details on party affiliation and occupational background, see Table 2 . The values in square brackets accommodate the fact that we use a semilogarithmic functional form with dummy variables. The coefficients of the percentage change for all dummy variables are computed using the post estimation Stata command "logdummy"

The results are presented in Table 3. In column I, we focus on absences on plenary sitting days as a measure of shirking. Controlling for all delegation-level and individuallevel covariates, we find that the coefficient for remuneration is positive and statistically significant at the $10 \%$ level. $^{19}$ This implies that higher pay is associated with more absenteeism. This result seems surprising, as it contradicts the hypothesis that pay has a disciplining effect on politicians. However, it is similar to the main finding by Mocan and Altindag (2013), who argue that the pay reform constitutes an increase in unearned income. ${ }^{20}$ Accordingly, better paid MEPs have weaker incentives to collect per-diem compensation, as this second part of the compensation package has become a relatively

\footnotetext{
${ }^{19}$ OLS does not produce estimated values outside the range of 0-100.

20 Their empirical strategy, however, differs from ours regarding the precise observation period under study, the inclusion of controls, the level of clustering, as well as the use of fixed effects.
} 
less important source of income. ${ }^{21}$ We look at three further measures of in-office effort in order to establish a broad basis for evaluating the impact of money on discipline. In column II, we find that increases in pay are positively related to the number of plenary speeches. The estimated coefficient for the basic salary can be interpreted as an elasticity of 0.17 , since we are looking at logarithms. A $10 \%$ increase in base pay is related to $1.68 \%$ more plenary speeches, ceteris paribus. In column III, we report a strong positive correlation between pay and the number of written declarations. With regard to the size of the coefficient, we find that a $10 \%$ increase in base pay is associated with a $1.48 \%$ increase in the number of written declarations, on average. A similar result — though with a smaller effect and measured with less precision-is found for the number of reports drafted in column IV. The latter three results are consistent with the hypothesis that more generous remuneration induces more discipline and leads to more in-office effort. With regard to the further explanatory variables, we find that the number of plenary speeches delivered increases with tenure in office and is higher when the MEP belongs to one of the major parties (EPP and S\&D) as well as when the MEP chairs a committee. The number of plenary speeches decreases with age and with the size of the MEP's political group. MEPs with a party affiliation, as compared to non-affiliated MEPs, overall, tend to submit fewer written declarations and to draft more reports. Chairing a committee significantly increases engagement in all legislative activities. ${ }^{22}$

\section{Sample restrictions according to differences in electoral rules}

Incentives to increase in-office effort and to reduce shirking, respectively, may differ according to national specificities of electoral rules. First, in countries with a closed-list proportional representation system (compared to an open-list system), electoral competition is less candidate-centered and party leaders rather than voters decide who is placed at the top of the list. In such a system, electoral forces might be weaker and the incentive effect of increases in pay on in-office effort might be less pronounced. Second, in member states where incompatibilities between the European and the (sub-)national levels exist, MEPs can dedicate more time to their parliamentary duties. One would expect a more pronounced positive effect of an increase in pay on in-office effort. Third, minimum vote requirements constitute a form of entry barrier and primarily impact party competition, giving an advantage to larger parties. Such restrictions may, however, also affect MEPs' behavior.

As we use a fixed effects model and these specific institutions of the national electoral system remained fixed during our observation period, we analyze sample restrictions according to differences in electoral rules. The results are presented in Table A.3 in the Online Appendix. We restrict the sample to member states which have (1) a closed-list proportional representation electoral system, (2) rules of incompatibility between the European and the (sub)national levels and (3) minimum vote requirements for national parties. Concentrating on the variable capturing the basic salary, a similar picture emerges. In all specifications, we find a positive relationship between pay and absenteeism, and between pay and the other measures of in-office effort. Compared to the full sample, we find no systematic pattern as to whether the change in in-office effort is less pronounced in

\footnotetext{
21 Another possible explanation is that if services provided to local constituencies are more important for reelection than parliamentary attendance, an increased value of office-holding after the reform might lead to the politician providing more services to local constituencies and thus to more parliamentary absenteeism.

22 As the reform was enacted in summer 2005, the results for the effect of remuneration on in-office effort might constitute lower limit estimates. MEPs might have started to alter their behavior directly after the 2005 enactment. Such anticipation effects would lead to an attenuation bias.
} 
countries with closed-list proportional representation systems or whether it is more pronounced in countries with restrictions on dual office-holding. ${ }^{23}$

Our results suggest that remuneration has a bearing on in-office effort. On the one hand, an increase in remuneration appears to reduce attendance. One possible explanation for this is the weaker incentive to collect per-diem allowances. On the other hand, we find more engagement in three legislative activities. This is consistent with the hypothesis that pay constitutes a disciplining device. The results hold if we look at sample restrictions according to differences in the national specificities of electoral rules. Importantly, the results suggest that one should not rely on only one measure of effort to evaluate the impact of pay on discipline in politics.

\subsection{Pay harmonization and political selection}

According to large parts of the theoretical literature and the previous empirical contributions, we expect that higher pay attracts better qualified politicians. We first look at the compositional effects in the legislative period before and after the reform. Second, we focus on the political selection of newly elected MEPs. Third, we consider extensions regarding the field of study.

We estimate the following linear probability model (OLS): ${ }^{24}$

$$
\begin{aligned}
\text { Quality of } \mathrm{MEP}_{\mathrm{i}, \mathrm{d}, \mathrm{t}}= & \beta_{0}+\beta_{1} \ln \left(\text { remuneration }_{\mathrm{d}, \mathrm{t}}\right)+\beta_{2} \mathrm{LP7}+\beta_{3} \mathrm{D}_{\mathrm{d}}+\beta_{4} \mathrm{X}_{\mathrm{d}, \mathrm{t}}+\beta_{5} \mathrm{Z}_{\mathrm{i}, \mathrm{d}, \mathrm{t}} \\
& +\epsilon_{\mathrm{i}, \mathrm{d}, \mathrm{t}},
\end{aligned}
$$

where the dependent variable is a dummy variable that indicates whether the individual MEP $i$ exhibits a certain (ex-ante) quality. The remaining variables are defined as above. The post-harmonization dummy variable, LP7, controls for a time trend in the quality of politicians. National delegation fixed effects are included to account for unobserved national delegation specific time-invariant factors affecting the quality of politicians. One might think of time-invariant differences between countries in the educational system as impacting the mix of MEPs' qualifications or those in labor market institutions as affecting occupational structures. In addition to adjusting for GDP and corruption at the country level, we control for individual characteristics to account for the possibility that MEPs of different genders, ages, and ideologies have systematically different educational, political and occupational backgrounds. For example, descriptive evidence on national politics suggests that conservative politicians are better educated and had highly skilled occupations (for instance, lawyers).

\section{All MEPs}

In Table 4, we present the estimation results for the sample of MEPs who were elected and neither retired early nor replaced other MEPs. In column I, we take the probability that the MEP has a university degree as our measure of (ex-ante) quality. In column II, we

\footnotetext{
${ }^{23}$ The results of the analysis of sample restrictions, however, have to be interpreted with caution. We identify the effect of pay on the basis of a smaller number of observations and, in particular, rely on the variation in pay for (far) fewer than 27 countries, which makes the computation of (robust) standard errors less reliable.

${ }^{24}$ We are aware of the challenges that come with the linear probability model as regards heteroscedasticity, distribution of errors and linearity. Therefore, we also ran the regressions with a logistic regression model. Applying a logit model causes a loss of observations owing to sparseness and the interpretation of the estimated coefficients is less straight forward. As the results generate coefficients of similar size when computing either marginal effects at the mean or average marginal effects, we prefer the linear probability model.
} 


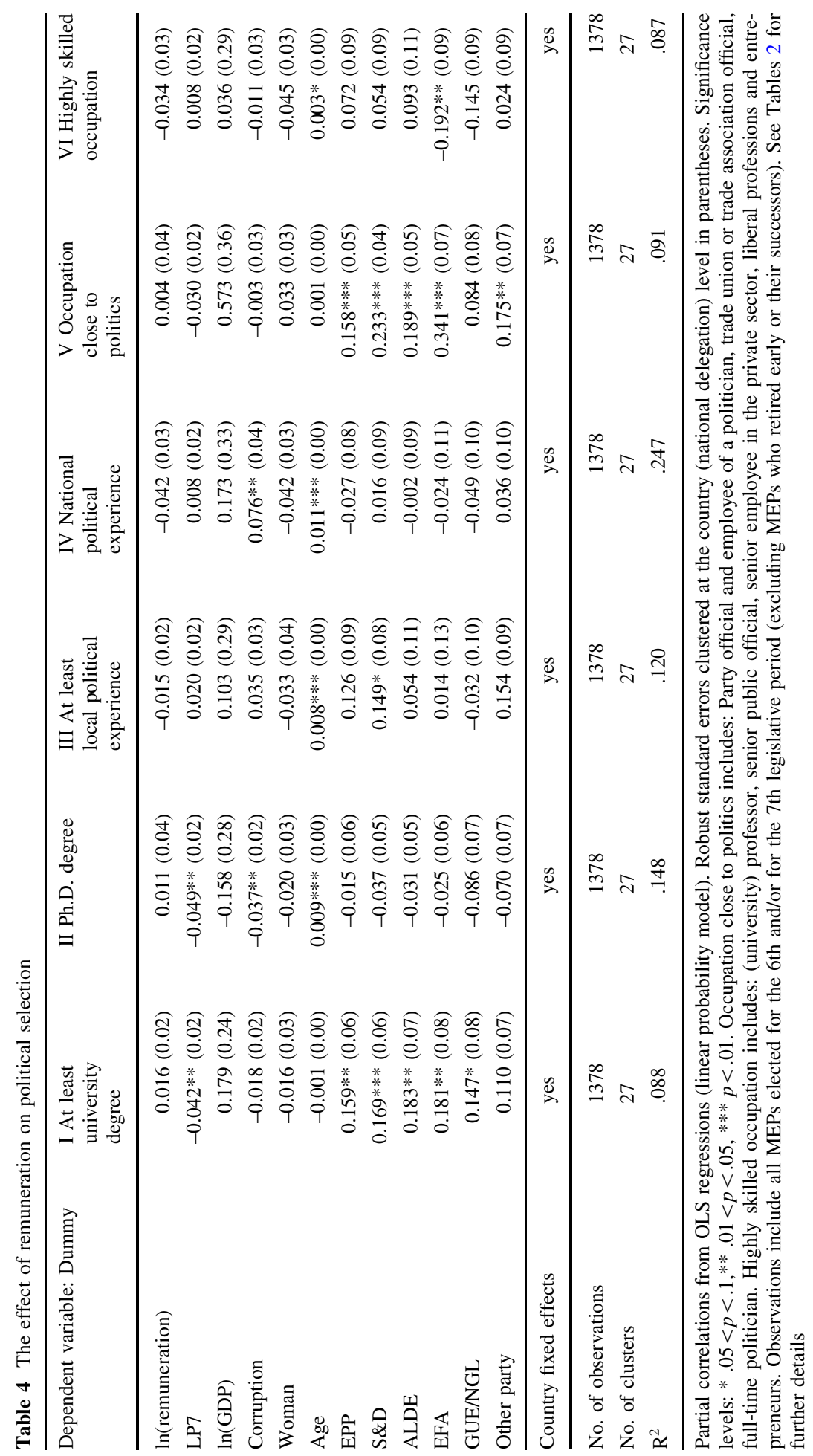


concentrate on the doctoral degree as a more selective indicator. In both columns, we find no statistically significant evidence suggesting that higher pay leads to a selection of formally better educated politicians. This result contrasts with the evidence presented by Fisman et al. (2013). They report a negative selection effect of higher pay on formal education of politicians, as approximated by the fraction of MEPs with a degree from the top 500 universities across the world provided by the 2010 Academic Ranking of World Universities. ${ }^{25}$ In columns III and IV, we concentrate on previous political experience in elected office. We find no statistically significant effect of pay on the probability that an MEP had held at least one local political office prior to election to the EP in column III. In contrast to our expectation, a negative (though not statistically significant) coefficient is found for the partial correlation between an MEP's pay and the probability that he or she had an elected office at the highest national level prior to election. We find no indication that higher pay systematically attracts more politicians previously employed in occupations close to politics (column V) or highly skilled occupations (column VI). With regard to the further explanatory variables, we find that the probability that an MEP has a university degree is greater when he or she is affiliated to a party compared to non-affiliated MEPs. Intuitively, MEPs belonging to a party are more likely to have had a previous occupation that was in an area close to politics.

Newly elected MEPs

The analysis of newly elected MEPs, all being successful candidates, is closer to the question of whether higher pay increases competition for parliamentary seats by influencing the incentives to enter politics and whether this leads to a different (improved) selection of politicians.

In Table 5, we run the same regressions as in the previous analysis and restrict our attention to the sample of newly elected MEPs for the 6th and 7th legislative periods and exclude MEPs who replaced those who retired. In columns I and II, positive partial correlations between pay and formal education emerge. However, the partial correlations are not statistically significant. With respect to the share of MEPs with at least local political experience, we find a negative (though not statistically significant) partial correlation. The effect of more pay on the share of newly elected MEPs with previous political experience at the highest national level is again-rather than positive, as expectednegative and statistically significant at the $1 \%$ level. As to the size of the coefficient, doubling the base pay is statistically significantly related to a 9.6 percentage points $(=\ln (2)$ $\mathrm{x} \beta_{1}$ ) decrease in the probability that an MEP has prior political experience at the highest national level. When looking at the selection of newly elected MEPs in terms of their occupational backgrounds, we find a negative partial correlation between pay and the share of MEPs with previous occupations close to politics, and a positive partial correlation with the share of MEPs with previous highly skilled occupations. Again, these partial corre-

\footnotetext{
${ }^{25}$ Regarding the parallel contribution by Fisman et al. (2013), we apply the same empirical strategy to, basically, the same data. Differences in the results for the part of the analysis that overlaps with theirs might, however, be because of the definition of the dependent variables, the inclusion or exclusion of countries (for the estimations on selection, we include Bulgaria and Romania), control variables (for instance, we include political group size, national delegation size, party affiliation and whether or not an MEP is chairing a committee or a delegation) or the precise legislative years under study.
} 


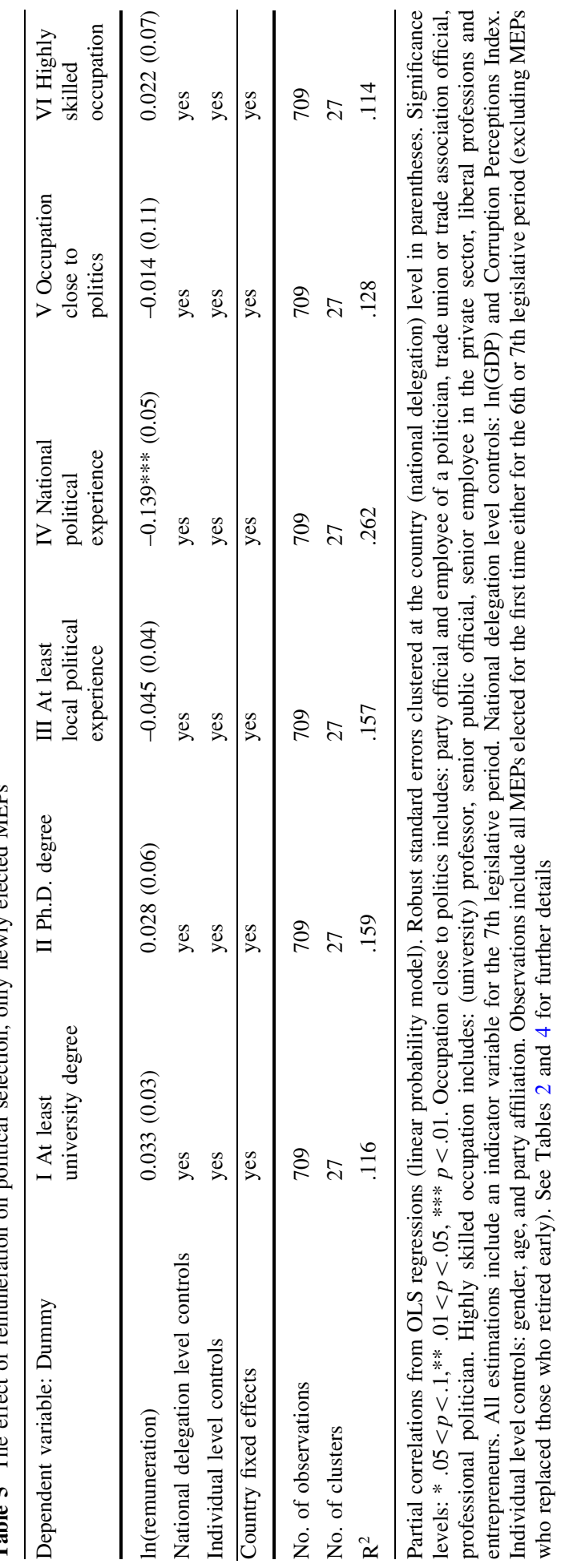


lations are not statistically significant. ${ }^{26}$

\section{Extension: field of study}

As a complementary analysis, we look at whether the selection of newly elected MEPs has changed in terms of their field of study rather than their level of formal education. We focus on newly elected MEPs who have either a university degree in law, in economics and business administration or in other social sciences (e.g., political science or sociology). ${ }^{27}$ These groups are of particular interest, since their fields of study are relatively closely related to politics. Moreover, individuals with a degree in law or economics tend to enter highly skilled occupations in the private or public sector, which implies high opportunity costs for entering politics. In Table 6 , we find a statistically significant positive partial correlation between pay and the probability that an MEP has a law degree. For this group with potentially high opportunity costs, a parliamentary seat appears more attractive the more generous the pay. In contrast, a negative (though not statistically significant) partial correlation is found between pay and the probability that an MEP has a degree in economics or business administration.

Overall, our results suggest that the positive relationship between pay and ex-ante quality, as found by previous work on the national or subnational level, may not necessarily hold and should be considered with more than one ex-ante quality dimension. Furthermore, more attention should be paid to the theoretical models that predict a negative relationship, for instance, Poutvaara and Takalo (2007) and Mattozzi and Merlo (2008).

\subsection{Pay harmonization and reelection}

On theoretical grounds, the change in the reelection rate is the result of at least two mechanisms. On the one hand, more generous pay increases the attractiveness of becoming a politician, which leads to fierce electoral competition for political office, which, in turn, is likely to reduce reelection chances. On the other hand, an (upcoming) increase in pay reinforces the reelectoral incentives of the incumbents as the value of remaining in office increases. This decreases the incentive to shirk and is likely to enhance reelection rates.

In Table 7, we focus on reelection and restrict our attention to the sample of MEPs who were elected for the 6th and 7th legislative periods (excluding all MEPs who replaced those who retired) from the 15 member states before expansion in 2004. In column I, adjusting for country-level covariates, we find that higher pay raises reelection rates. This finding is robust to the inclusion of individual controls in column II. Doubling the base pay

\footnotetext{
${ }^{26}$ In supplementary analyses, we investigated whether our results on political selection are driven by sample selection. First, in contrast to the finding of Kotakorpi and Poutvaara (2011), no evidence is found for systematic differences between the selection effects among women and men when looking at formal education (see Table A.4 in the Online Appendix, columns I and II). Second, as the potentially higher attractiveness of national parliamentary seats, in terms of reputation and decision-making power, might dissuade high-quality candidates from running for an EP seat, our results might be driven by the countries in which national elections take place in the same year as the EP elections. Excluding these countries, we find no different pattern (see Table A.5 in the Online Appendix). In the older member states with established selection procedures into the EP, the pool of candidates might react more strongly to a pay reform, as a seat in the EP is an established and relevant career option. For the corresponding sample restriction, we find more pronounced positive (education, Ph.D. degree) and negative (previous political experience) selection effects (see Table A.6 in the Online Appendix).

27 An early contribution on lawyers as legislators is presented by McCormick and Tollison (1978). They argue that lower parliamentary pay (indicative of a part-time parliament) attracts more lawyers as it is more compatible with their outside activities. However, the focus of their analysis is on the determinants of parliamentary pay.
} 
Table 6 The effect of remuneration on political selection in terms of field of study, only newly elected MEPs

\begin{tabular}{|c|c|c|c|}
\hline Dependent variable: Dummy & I Degree in law & II Degree in economics & $\begin{array}{l}\text { III Degree in } \\
\text { other social sciences }\end{array}$ \\
\hline $\ln ($ remuneration $)$ & $0.129 * * *(0.04)$ & $-0.087(0.05)$ & $-0.010(0.04)$ \\
\hline LP7 & $-0.007(0.05)$ & $-0.045(0.04)$ & $0.096^{* *}(0.05)$ \\
\hline $\ln (\mathrm{GDP})$ & $-1.346^{* * *}(0.37)$ & $1.573 * * *(0.52)$ & $-0.078(0.42)$ \\
\hline Corruption & $0.048(0.05)$ & $-0.139 * * *(0.05)$ & $0.008(0.04)$ \\
\hline Woman & $0.010(0.04)$ & $-0.020(0.04)$ & $-0.024(0.03)$ \\
\hline Age & $-0.002(0.00)$ & $-0.001(0.00)$ & $-0.005 * * *(0.00)$ \\
\hline EPP & $-0.019(0.05)$ & $0.056(0.05)$ & $-0.061(0.07)$ \\
\hline $\mathrm{S} \& \mathrm{D}$ & $-0.093(0.07)$ & $0.115^{*}(0.06)$ & $-0.058(0.08)$ \\
\hline ALDE & $0.027(0.06)$ & $0.105(0.06)$ & $-0.077(0.08)$ \\
\hline EFA & $-0.165 * *(0.07)$ & $-0.044(0.06)$ & $0.007(0.07)$ \\
\hline GUE/NGL & $-0.121 *(0.07)$ & $-0.002(0.08)$ & $0.000(0.08)$ \\
\hline Other party & $-0.078(0.06)$ & $0.103(0.06)$ & $-0.094(0.08)$ \\
\hline Country fixed effects & yes & yes & yes \\
\hline No. of obs. & 709 & 709 & 709 \\
\hline No. of clusters & 27 & 27 & 27 \\
\hline $\mathrm{R}^{2}$ & .096 & .075 & .080 \\
\hline
\end{tabular}

Partial correlations from OLS regressions (linear probability model). Robust standard errors clustered at the country (national delegation) level in parentheses. Significance levels: * .05<p<.1,**.01<p<.05, *** $p<.01$. Dependent variables: Degree in economics also includes business administration; Other social sciences includes political science and international relations, sociology, psychology, history, and journalism. Observations include all MEPs elected for the first time either to the 6th or 7th legislative period (excluding MEPs who replaced those who retired early). See Tables 2 and 4 for further details

statistically significantly increases the probability of reelection by 17.7 percentage points $\left(=\ln (2) \times \beta_{1}\right)$. This lends support to the argument that incumbents who expect the value of holding office to increase in future will make use of their incumbent position in order to curry favor with the party leader and/or when they compete for electoral votes.

\section{Concluding remarks}

This paper has studied the remuneration of politicians as an important institutional determinant of the disciplining and selection effects. In particular, we exploited the EP pay harmonization, implemented in 2009, which provides data on a pool of politicians from the 27 member states that concurrently adapted to radical changes in pay. Apart from strongly varying patterns in the composition of national delegations in terms of ex-ante quality, we find that increases in pay have a positive incentive effect on engagement in legislative activities. However, more generous remuneration is associated with higher rates of absenteeism. With respect to political selection, we find that higher pay raises reelection rates. The composition of the pool of MEPs in terms of (ex-ante) quality is, however, 
Table 7 The effect of remuneration on reelection, dependent variable: reelection dummy

\begin{tabular}{|c|c|c|}
\hline & I & II \\
\hline $\ln ($ remuneration $)$ & $0.371 * * *(0.08)$ & $0.263 * * *(0.07)$ \\
\hline LP7 & $-0.034(0.05)$ & $-0.026(0.02)$ \\
\hline $\ln (\mathrm{GDP})$ & $-1.582 *(0.79)$ & $-0.864(0.51)$ \\
\hline Corruption & $0.129(0.09)$ & $0.119 * *(0.05)$ \\
\hline Woman & & $0.023(0.02)$ \\
\hline Age & & $-0.000(0.00)$ \\
\hline Tenure & & $0.300 * * *(0.02)$ \\
\hline EPP & & $0.102(0.06)$ \\
\hline S\&D & & $0.080(0.06)$ \\
\hline ALDE & & $0.049(0.06)$ \\
\hline EFA & & $0.066(0.05)$ \\
\hline GUE/NGL & & $0.100 *(0.06)$ \\
\hline Other party & & $0.061(0.06)$ \\
\hline University degree & & $0.005(0.03)$ \\
\hline At least local political experience & & $0.033(0.02)$ \\
\hline Highly skilled and close to politics occupation & & $0.039 *(0.02)$ \\
\hline Country fixed effects & yes & yes \\
\hline No. of observation & 991 & 990 \\
\hline No. of clusters & 15 & 15 \\
\hline $\mathrm{R}^{2}$ & .092 & .570 \\
\hline
\end{tabular}

Partial correlations from OLS (linear probability model). Robust standard errors clustered at the country (national delegation) level. Significance levels: * .05<p<.1,**.01<p<.05, ***<.01. Observations from the 15 (older) member states are included

unaffected by the reform. If we restrict our attention to newly elected MEPs, we find that more pay is related to fewer MEPs with political experience at the highest national level, indicating lower ex-ante quality. Overall, our results support the view that rules governing remuneration have a bearing on the discipline of political agents. In contrast to recent empirical work on local or national politicians, no support is found for the role of more generous pay in systematically improving the (ex-ante) quality of politicians.

The latter result, in particular, calls for further discussion. We provide evidence suggesting that forces are at work preventing significant changes in the composition of the pool of MEPs, i.e., the reform leads to a higher reelection rate of incumbents. Electoral competition seems to favor incumbent MEPs. This lower turnover, however, does not explain why we do not find a selection of newly elected MEPs with better ex-ante quality. In trying to better understand this result, one must take into account the European proportional electoral rule and the correspondingly important role of national parties in nominating candidates. If national parties control entry into the EP and allocate seats either to inexperienced politicians with ambitions at the national level as a form of training arena or to politicians who are about to retire, changes in pay are likely to be of secondary importance. In this case, the EP is rather a laboratory experiment for studying the decisions of parties in selecting and allocating candidates to different levels of government. A final 
argument concerns the timing of our analysis. As career paths into the EP are anecdotally reported to be quite stable (see, e.g., Scarrow 1997) and the overall supply of politicians tends to be fixed in the short run, we identify only weak short-run selection effects in the present study, while selection patterns may change with a substantial lag. Initial changes may occur at the candidate level, e.g., the number and quality of candidates running for a seat.

Acknowledgments I am grateful to the editor William F. Shughart II, three anonymous referees, Gabrielle Fack, Patricia Funk, Thorsten Henne, Krisztina Kis-Katos, Stephan Litschig, Ulrich Matter, Tommaso Nannicini, Reto Odermatt, Michaela Slotwinski, Alois Stutzer and participants at the UPF LPD Seminar, the BACT Seminar at Erasmus University Rotterdam, the SSES Meeting in Neuenburg, the FFA Brown Bag Seminar in Berne and the EPCS meeting in Cambridge for helpful comments. I also thank the Swiss National Science Foundation for financial support and the Department of Economics at Pompeu Fabra University, Barcelona for its hospitality. Special thanks go to Charlotte Ruetz and Laura Sochaczewski for excellent research assistance and to Barbara Schlaffer Bruchez and Hermione Miller Moser for copyediting.

\section{References}

Barro, R. (1973). The control of politicians: An economic model. Public Choice, 14, 19-42.

Bender, B., \& Lott, J. R. Jr. (1996). Legislator voting and shirking: A critical review of the literature. Public Choice, 87(1-2), 67-100.

Benedetto, G. (2005). Rapporteurs as legislative entrepreneurs: The dynamics of the codecision procedure in Europe's parliament. Journal of European Public Policy, 12(1), 67-88.

Besley, T. (2004). Paying politicians. Journal of the European Economic Association, 2(2-3), 193-215.

Besley, T. (2005). Political selection. Journal of Economic Perspectives, 19(3), 43-60.

Besley, T., \& Larcinese, V. (2011). Working or shirking? Expenses and attendance in the UK parliament. Public Choice, 146(3-4), 291-317.

Besley, T., \& Reynal-Querol, M. (2011). Do democracies select more educated leaders? American Political Science Review, 105(3), 552-566.

Braendle, T. (2013). Do institutions affect citizens' selection into politics? WWZ Discussion Paper 2013/04, University of Basel.

Braendle, T., \& Stutzer, A. (2010). Public servants in parliament: Theory and evidence on its determinants in Germany. Public Choice, 145(1-2), 223-252.

Braendle, T., \& Stutzer, A. (2011). Selection of public servants into Politics. WWZ Discussion Paper 06/11. University of Basel.

Brennan, G., \& Hamlin, A. (2000). Democratic devices and desires. Cambridge: Cambridge University Press.

Buchanan, J. M., Tollison, R. D., \& Tullock, G. (1980). Toward a theory of the rent-seeking society. College station: Texas A\&M Press.

Caselli, F., \& Morelli, M. (2004). Bad politicians. Journal of Public Economics, 88(3-4), 759-782.

Chattopadhyay, R., \& Duflo, E. (2004). Women as policy makers: Evidence from a randomized policy experiment in India. Econometrica, 72(5), 1409-1443.

Congleton, R. D., Hillman, A. L., \& Konrad, K. A. (Eds.) (2008). 40 years of research on rent seeking (Vols 1. and 2). Heidelberg: Springer.

Cooter, R. D. (2002). Who gets on top in democracy? Elections as filters. Supreme Court Economic Review, $10,127-141$.

Corbett, R., Jacobs, F., \& Shackleton, M. (2005). The European Parliament (6th ed.). London: John Harper Publishing.

Couch, J. F., Atkinson, K. E., \& Shughart, W. F, II. (1992). Ethics laws and the outside earning of politicians: The case of Alabama's 'legislator-educators'. Public Choice, 73(2), 134-145.

Eggers, A. C., \& Hainmueller, J. (2009). MP's for sale? Returns to office in postwar British politics. American Political Science Review, 103(4), 513-533.

Fearon, J. D. (1999). Electoral accountability and the control of politicians: Selecting good types versus sanctioning poor performance. In A. Przeworski, S. C. Stokes, \& B. Manin (Eds.), Democracy, accountability, and representation (pp. 55-97). Cambridge: Cambridge University Press. 
Ferraz, C., \& Finan, F. (2009). Motivating politicians: The impacts of monetary incentives on quality and performance. NBER Working Paper No. 14906, Cambridge, MA.

Fisman, R., Harmon, N. A., Kamenica, E., \& Munk, I. (2013). Labor supply of politicians. Princeton: Princeton University.

Gagliarducci, S., \& Nannicini, T. (2013). Do better paid politicians perform better? Disentangling incentives from selection. Journal of the European Economic Association, 11(2), 369-398.

Gagliarducci, S., Nannicini, T., \& Naticchioni, P. (2010). Moonlighting politicians. Journal of Public Economics, 94(9-10), 688-699.

Galasso, V., \& Nannicini, T. (2011). Competing on good politicians. American Political Science Review, 105(1), 79-99.

Gehlbach, S., Sonin, K., \& Zhuravskaya, E. (2010). Businessman candidates. American Journal of Political Science, 54(3), 718-736.

Groseclose, T., \& Krehbiel, K. (1994). Golden parachutes, rubber checks and strategic retirements from the 102d House. American Journal of Political Science, 38(1), 75-99.

Hix, S. (2004). Electoral institutions and legislative behavior: Explaining voting defection in the European Parliament. World Politics, 56(1), 194-223.

Hobolt, S. B., \& Hoyland, B. (2011). Selection and sanctioning in European parliamentary elections. British Journal of Political Science, 41(3), 477-498.

Kaeding, M. (2004). Rapporteurship allocation in the European Parliament. Information or distribution? European union. Politics, 5(3), 355-373.

Keane, M. P., \& Merlo, A. (2010). Money, political ambition, and the career decisions of politicians. American Economic Journal: Microeconomics, 2(3), 186-215.

Kennedy, P. E. (1981). Estimation with correctly interpreted dummy variables in semilogarithmic equations. American Economic Review, 71(4), 801.

Kotakorpi, K., \& Poutvaara, P. (2011). Pay for politicians and candidate selection: An empirical analysis. Journal of Public Economics, 95(7-8), 877-885.

Lehmann, W. (2009). The European elections: EU-legislation, national provisions and civic participation. Brussels: European parliament constitutional affairs study.

Lott, J. R, Jr. (1987). Political cheating. Public Choice, 52(2), 169-186.

Mamadouh, V., \& Raunio, T. (2003). The committee system: Power, appointments, and report allocation. Journal of Common Market Studies, 41(2), 333-351.

Mansbridge, J. (2009). A selection model of political representation. Journal of Political Philosophy, 17(4), 369-398.

Mattozzi, A., \& Merlo, A. (2008). Political careers or career politicians? Journal of Public Economics, 92(3-4), 597-608.

Mattozzi, A., \& Merlo, A. (2011). Mediocracy. PIER working paper No. 11-002. Penn Institute for Economic Research: University of Pennsylvania.

McCormick, R. E., \& Tollison, R. (1978). Legislatures as unions. Journal of Political Economy, 86(1), 243-277.

Merlo, A., Galasso, V., \& Landi, M. (2010). The labor market of Italian politicians. In T. Boeri, A. Merlo, \& A. Prat (Eds.), The ruling class: Management and politics in modern Italy (pp. 9-107). Oxford: Oxford University Press.

Meserve, S. A., Pemstein, D., \& Bernhard, W. T. (2012). Brussels bound: Candidate selection in European elections. Lubbock, Texas: Texas Tech University.

Messner, M., \& Polborn, M. K. (2004). Paying politicians. Journal of Public Economics, 88(12), 2423-2445.

Mocan, N. H., \& Altindag, D. T. (2013). Salaries and work effort: An analysis of the European Union parliamentarians. Economic Journal, 123(573), 1130-1167.

Nohlen, D. (2004). Wie wählt Europa? Das polymorphe Wahlsystem zum Europäischen Parlament. Aus Politik und Zeitgeschichte, 17, 29-37.

Norris, P., \& Franklin, M. (1997). Social representation. European Journal of Political Research, 32(2), $185-210$.

Padovano, F. (2013). Are we witnessing a paradigm shift in the analysis of political competition? Public Choice, 156(3-4), 631-651.

Parker, G., \& Parker, S. L. (2009). Earning through learning in legislatures. Public Choice, 141(3-4), 319-333.

Poutvaara, P., \& Takalo, T. (2007). Candidate quality. International Tax and Public Finance, 14(1), 7-27.

Rosenson, B. (2006). The impact of ethics laws on legislative recruitment and the occupational composition of state legislatures. Political Research Quarterly, 59(4), 619-627. 
Scarrow, S. (1997). Political career paths and the European Parliament. Legislative Studies Quarterly, 22(2), 253-263.

Schindler, P. (1999). Datenhandbuch zur Geschichte des Deutschen Bundestages 1949-1999. Baden-Baden: Nomos.

Stigler, G. J. (1971). The theory of economic regulation. Bell Journal of Economics and Management Science, 2, 137-146.

Tullock, G. (1967). The welfare costs of tariffs, monopolies and theft. Western Economic Journal, 5, 224-232.

Vaubel, R. (1994). The political economy of centralization and the European Community. Public Choice, 81(1-2), 151-190.

Vaubel, R. (2013). International organizations. In M. Reksulak, L. Razzolini, \& W. F. Shughart II (Eds.), The Elgar Companion to Public Choice (2nd ed., pp. 451-468). Cheltenham, UK and Northampton, MA, USA: Edward Elgar. 